\title{
Erratum to: Improved response-time bounds in fixed priority scheduling with arbitrary deadlines
}

\author{
Werner Grass $^{1}$ (D) Thi Huyen Chau Nguyen ${ }^{2}$
}

\section{Erratum to: Real-Time Syst DOI 10.1007/s11241-017-9282-7}

Unfortunately, the below acknowledgement text was not submitted and not published in the original article.

This research is funded by Vietnam National Foundation for Science and Technology Development (NAFOSTED) under grant number 102.03-2014.23.

The online version of the original article can be found under doi:10.1007/s11241-017-9282-7.

Werner Grass

grass@fim.uni-passau.de

Thi Huyen Chau Nguyen

chaunth@thanglong.edu.vn

1 University of Passau Faculty of Computer Science and Mathematics, Innstr. 43, 94032 Passau, Germany

2 Department of Information Technology, Thang Long University (TLU), Dai Kim, Hoang Mai, Hanoi, Vietnam 